\title{
Growth Pattern, Nutrient use Ratio and Nutrient Harvest Index as Influenced by Nutrient Management in Pearlmillet
}

\author{
Manjeet* and Parveen Kumar \\ Department of Agronomy, CCS Haryana Agricultural University, Hisar, India \\ *Corresponding author
}

Keywords

Pearl millet, Growth rate, Manures,

Nutrient use

efficiency and

Nutrient harvest

index

\section{Article Info}

Accepted:

15 July 2018

Available Online:

10 August 2018

\section{A B S T R A C T}

\begin{abstract}
A field experiment was conducted at Agronomy Research Area, CCSHAU, HISAR during Kharif 2016 with the objective to study the influence of organic and inorganic nutrient source on growth pattern, nutrient efficiency ratio and nutrient harvest index of pearl millet. The experiment was conducted in split plot design with three replications. In the main plot there were manurial treatment viz. control, biomix, vermicompost @ $2.5 \mathrm{t} \mathrm{ha}^{-1}$ and vermicompost @ $2.5 \mathrm{t} \mathrm{ha}^{-1}+$ biomix and nitrogen levels viz. 70, 80, 90 and 100 per cent RDN were kept under subplot. The growth parameters viz. Leaf area ratio, Leaf area duration and Net assimilation rate etc. were calculated varied significantly among different treatments. The nutrient use efficiency and nutrient harvest index was found significantly varying under different treatment and was found highest in control in case of manurial treatment and in $70 \%$ RDN which was at par with $80 \%$ RDN but significantly higher over $90 \% \mathrm{RDN}$ and $100 \% \mathrm{RDN}$ in case of different nitrogen levels.
\end{abstract}

\section{Introduction}

Pearl millet [Pennisetum glaucum (L.) R. Br. Emend. Stuntz] is one of the most extensively cultivated cereal crops in the environmental conditions with limited and erratic rainfall, high temperature and poor soil condition with low nutrient levels too harsh for other cereals crops (Renu et al., 2017). It is impossible to beat the pearl millet in growing it in the world's hardest agricultural production environment, due to its capacity to extract mineral nutrition and water even from the poorest soils. Pearl millet grain has higher protein content (11.6\%), carbohydrate (67.3\%), fat (5\%) and fiber (12\%), higher level of iron and zinc and insoluble dietary fiber (Sinha, 2015). To meet the ever growing food demand with limited resources, we need to increase the productivity by adopting better agronomic practices and efficient fertilization. Today, it is getting more attention due to increasing evidence of less seasonal rainfall, terminal heat, frequent occurrence of extreme weather events coupled with scanty water resources (Singh et al, 2013a). The increase in crop production has been mainly resulted from the application of N-P-K fertilizers (Brady and 
Weil, 2002). Pearl millet responds favorably to the application of fertilizers particularly nitrogenous, which is supplied mostly through chemical fertilizers, FYM, vermicompost and biofertilizers. Nitrogenous fertilizers have played a key role in increasing food grains production in India and will continue to do so in future (Singh et al, 2013b). Vermicompost is a rich mixture of macro and micro plant nutrients and increases the microbial activity and when applied, the soil will be enriched with a variety of nutrients particularly micronutrients and also increase the availability of other nutrients. So, the role of earthworms in maintaining soil fertility is well known and recently, emphasis is laid on their use for breaking down and stabilizing the organic waste (Hameeda et al., 2006). Similarly, Bio-fertilizers possess unique ability to fix atmospheric nitrogen either by living symbiotically or non symbiotically (free living) or by transforming native soil nutrients such as phosphorus, zinc, sulphur, copper etc. from the non-usable form to usable form through biological processes (Sahai, 2011). These micro-organisms fix about $20-40 \mathrm{~kg}$ $\mathrm{N} / \mathrm{ha} /$ year in the field and also secret some growth promoting substances (Rinku et al., 2014). So, in order to sustain its productivity, use of organic source of nutrients in combination with inorganic fertilizers is necessary not only to maintain soil fertility but also to improve the efficacy of chemical fertilizers (Bagla et al., 2008).

\section{Materials and Methods}

A field experiment was conducted during Kharif season 2016 at Agronomy Research Area, Chaudhary Charan Singh Haryana Agricultural University, Hisar to study influence of organic and inorganic source on growth pattern, nutrient use ratio and nutrient harvest index of pearlmillet. The experiment was laid out in split plot design with three replications. In the main plot manurial treatment viz. control, biomix, vermicompost @ $2.5 \mathrm{t} \mathrm{ha}^{-1}$ and vermicompost @ $2.5 \mathrm{t} \mathrm{ha}^{-1}+$ biomix and in sub plot nitrogen levels viz. 70, 80, 90 and 100 per cent RDN were kept. The soil was sandy loam in texture, slightly alkaline in reaction, low in organic carbon and nitrogen $(133 \mathrm{~kg} / \mathrm{ha})$, medium in available phosphorus (18.3 kg/ha) and potassium (263 $\mathrm{kg} / \mathrm{ha}$ ). The pearlmillet hybrid 'HHB 223' was sown at a spacing of $45 \mathrm{~cm}$ at about $2.0 \mathrm{~cm}$ depth by using $5 \mathrm{~kg}$ seed $\mathrm{ha}^{-1}$. The seed pertaining to inoculated plots was treated with biomix culture, as per treatment. Full dose of phosphorus and half nitrogen, as per treatments, were applied at the time of sowing and remaining half of the nitrogen was top dressed in two splits, one after thinning and gap filling, and another at the time of ear head formation stage.

\section{Statistical analysis}

The data presented are the mean values of different measurements. The statistical method described by Panse and Sukhatme (1961) was followed for statistical analysis and interpretation of the experimental results. In order to evaluate the comparative performance of the various treatments, the data were analysed by the technique of analysis of variance described by Fisher (1950). All the tests of significance were made at $5 \%$ level of significance. To judge the significance of difference between two treatments, critical difference (CD) was worked out by the following formula:

$$
\mathrm{CD}=\sqrt{\frac{2 \mathrm{x} \text { Error variance }}{\mathrm{n}}} \mathrm{xt} \text { value at error of d.f. }
$$


Where,

n- number of observation averaged

t- Value from Fisher's and Yates's table (1950) for error degree of freedom at $5 \%$ level of significance

CD- Critical difference

Observations and Methods of Analysis: The observations regarding various growth parameters, nutrient efficiency ratio and nutrient harvest index and yield were recorded as:

1. Absolute Growth Rate (AGR): It expresses the dry weight increase per unit time and expressed in $\mathrm{g} /$ plant/day.

$\mathrm{AGR}=\frac{\mathrm{w}_{2}-\mathrm{w}_{1}}{(\mathrm{t} 2-\mathrm{t} 1)}$

Where, $\mathrm{W}_{2}$ and $\mathrm{W}_{1}$ are the total dry weights per plant at time $t_{2}$ and $t_{1}$ respectively.

2. Leaf Area Ratio (LAR): It is the ratio of leaf area to total plant biomass. It is a measure of leafiness relative to respiratory mass. It is expressed in $\mathrm{cm}^{2} / \mathrm{g}$.

LAR $=\frac{\text { Leaf area of plant }}{\text { Total dry weight of plant }}$

3. Leaf Area Duration (LAD): It is the integral of leaf area index over a growth period and expressed in days. Leaf area duration of a crop is a measure of its ability to produce leaf area on unit area of land over a time period.

$\mathrm{LAD}=\frac{\mathrm{LAI} 1+\mathrm{LAI} 2}{2} *(\mathrm{t} 2-\mathrm{t} 1)$

Where, LAD $=$ Leaf area duration between $\mathrm{t}_{2}$ and $\mathrm{t}_{1}$

$\mathrm{LAI}_{1}=$ Leaf area at time $\mathrm{t}_{1}$

$\mathrm{LAI}_{2}=$ Leaf area at time $\mathrm{t}_{2}$

4. Biomass Duration (BMD): The BMD is the integral of total biomass over a growth period and is expressed in $\mathrm{g}$ days.
$\mathrm{BMD}=\frac{\mathrm{TDM} 1+\mathrm{TDM} 2}{2} *(\mathrm{t} 2-\mathrm{t} 1)$

Where, $\quad \mathrm{BMD}=$ Biomass duration between $\mathrm{t}_{2}$ and $\mathrm{t}_{1}$

$\mathrm{TDM}_{1}=$ Total dry matter at time $\mathrm{t}_{1}$

$\mathrm{TDM}_{2}=$ Total dry matter at time $\mathrm{t}_{2}$

5. Net Assimilation Rate (NAR): It indirectly indicates the rate of net photosynthesis. It is expressed as g of dry matter production per day per $\mathrm{m}^{2}$ leaf area.

$\mathrm{NAR}=\frac{(w 2-W 1) *(\ln L 2-\ln L 1)}{(t 2-t 1) *(L 2-L 1)}$

$\mathrm{L}_{1} \& \mathrm{~W}_{1}=$ Leaf area and dry weight of the plant, respectively at time $\mathrm{t}_{1}$

$\mathrm{L}_{2} \& \mathrm{~W}_{2}=$ Leaf area and dry weight of the plant, respectively at time $t_{2}$

6. Tiller Production Rate (TPR): It was estimated by counting the number of tiller on tagged plants at 20 and 40 DAS after interval. It is expressed as number of tillers/day.

$\mathrm{TPR}=\frac{\operatorname{Tn} 2-\operatorname{Tn} 1}{(\mathrm{t} 2-\mathrm{t} 1)}$

$\operatorname{Tn}_{1}=$ Numbers of tillers at times $\mathrm{t}_{1}$

$\mathrm{Tn}_{2}=$ Numbers of tillers at times $t_{2}$

7. Nutrient Efficiency Ratio (NER): Nutrient efficiency ratio is the total biomass produced per unit of the nutrient uptake. It is expressed as $\mathrm{kg} / \mathrm{kg}$.

Nutrient Efficiency Ratio $(\mathrm{NER})=\frac{\mathrm{BY}}{\mathrm{NU}}$

Where, $B Y=$ Biological yield

$\mathrm{NU}=$ Nutrient uptake

8. Nutrient Harvest Index (NHI): Nutrient harvest index is the ratio of nutrient uptake by grains (or economic yield) to total nutrient uptake. It can also be expressed in percentage. 
Nutrient harvest Index =

Nutrient uptake by grain (or economic yield)

Total nutrient uptake for production of biological yield

9. Yield: The dried earheads of pearl millet from each plot were threshed to record grain yield per plot, which was converted to grain yield per hectare $\left(\mathrm{Mg} \mathrm{ha}^{-1}\right)$. The pearl millet stover after separating the earhead at harvest was left in the plots for sun drying. After proper drying, it was weighed to record the stover yield per plot and converted into stover yield per hectare $\left(\mathrm{Mg} \mathrm{ha}^{-1}\right)$.

\section{Results and Discussion}

The results revealed that different manurial treatment as well as the nitrogen levels application had significant variation on different growth characters, nutrient use ratio, nutrient harvest index and total nutrient uptake. The growth characters viz. NAR, AGR, LAD, BMD and TPR were improved as the fertility levels increased either by manurial or nitrogen application. In general, leaf area ratio and NAR decreases significantly with the advancement of the crop growth due to increase in the leaf area and total dry weight of the plant respectively and same trend was followed with the fertility level thus lowest value was recorded in treatment Biomix + Vermicompost@2.5 $\mathrm{t} \mathrm{ha}^{-1}$. The NAR was maximum (20.1) between 20-40 DAS because of the higher LAI and leaf area during this period associated with grand growth phase and thereafter it decreases. Leaf area duration and Biomass duration also varied significantly with different manurial treatment and nitrogen levels. In manurial treatments highest values (64.8 days) and (1258.0 g days), respectively were obtained in biomix + vermicompost @ $2.5 \mathrm{t} \mathrm{ha}^{-1}$ with in interval of 40-60 DAS. Similarly, absolute growth rate increase significantly with increasing level of nitrogen up to 100 per cent RDN which did not differ significantly with 90 per cent RDN. The maximum value of AGR was obtained in the interval of 20-40 DAS with $100 \%$ RDN (2.17 $\mathrm{g} /$ plant/day). However, the lowest value (1.55 $\mathrm{g} / \mathrm{plant} /$ day) of this character was recorded in treatment where 70 per cent RDN was applied. The tiller production rate (TPR) was calculated between interval of 20-40 DAS and its values varied from 0.19 to 0.24 tillers/day/Plant among the treatments. Application of organic manures such as vermicompost improves the physical condition of soil, provide complimentary environment for microorganisms. The plant growth is a function of cell division and cell enlargement, which depends upon availability of nutrient, especially nitrogen. Adequate supply of this nutrient element to crop has important role in the synthesis of carbohydrates, protein and lipids by the plants. The role of nitrogen in synthesizing the protoplasm and other body building materials of plant are well documented. The increase in auxin supply with higher level of nitrogen brought about increase in tillers per plant. Similar results were reported by Sinha et al. (2011) and Rathore (2006). But, there was reverse trend in case of LAR. The maximum value was obtained in interval of 0-20 DAS and associated with lower level of the nitrogen i.e. $70 \%$ RDN $\left(151.0 \quad \mathrm{~cm}^{2} / \mathrm{g}\right)$. This can be attributed to the point that with the increasing dose of nitrogen or with the application of biofertilizers and vermicompost the increase in the total dry weight of the plant was more as compared to the leaf area of the plant. Nutrient efficiency ratio (nitrogen, phosphorus and potassium) also decreases with the increasing level of nutrient. The nitrogen and phosphorus use efficiency are significantly affected by the manurial treatments and the different nitrogen levels and the maximum values were obtained with $70 \% \mathrm{RDN}$ and were $(118.6 \mathrm{~kg} / \mathrm{kg}, 478.7 \mathrm{~kg} / \mathrm{kg}$ respectively) and potassium use efficiency was found nonsignificant with different doses of nitrogen (Table 1 and 2). 
Table.1

\begin{tabular}{|c|c|c|c|c|c|c|c|c|c|c|c|c|c|c|c|}
\hline \multirow[t]{2}{*}{ Treatment } & \multicolumn{3}{|c|}{$\begin{array}{l}\text { Leaf area ratio } \\
\left(\mathrm{cm}^{2} / \mathrm{g}\right)\end{array}$} & \multicolumn{2}{|c|}{$\begin{array}{l}\text { NAR } \\
\left(\mathrm{g} / \mathrm{m}^{2} / \text { day }\right)\end{array}$} & \multicolumn{3}{|c|}{$\begin{array}{l}\text { Leaf area duration } \\
\text { (days) }\end{array}$} & \multicolumn{3}{|c|}{$\begin{array}{l}\text { BMD } \\
\text { (g days) }\end{array}$} & \multicolumn{3}{|c|}{$\begin{array}{l}\text { AGR } \\
\text { (g/plant/day) }\end{array}$} & \multirow{2}{*}{$\begin{array}{l}\text { TPR } \\
20- \\
40\end{array}$} \\
\hline & $0-20$ & $\begin{array}{l}20- \\
40\end{array}$ & $40-60$ & $\begin{array}{l}20- \\
40\end{array}$ & $\begin{array}{l}40- \\
60\end{array}$ & $0-20$ & $\begin{array}{l}20- \\
40\end{array}$ & $\begin{array}{l}40- \\
60\end{array}$ & $0-20$ & $\begin{array}{l}20- \\
40\end{array}$ & $40-60$ & $0-20$ & $\begin{array}{l}20- \\
40\end{array}$ & $\begin{array}{l}40- \\
60\end{array}$ & \\
\hline \multicolumn{16}{|l|}{ Manures } \\
\hline Control & 148.9 & 46.9 & 14.7 & 16.8 & 9.6 & 12.1 & 46.7 & 55.3 & 36.0 & 416.7 & 1007.8 & 0.18 & 1.72 & 1.23 & 0.21 \\
\hline Biomix & 133.6 & 43.2 & 13.8 & 18.4 & 9.7 & 12.4 & 48.4 & 57.4 & 41.0 & 467.9 & 1111.5 & 0.20 & 1.93 & 1.28 & 0.22 \\
\hline $\begin{array}{l}\text { Vermicompost } \\
@ 2.5 \mathrm{t} \mathrm{ha}^{-1}\end{array}$ & 132.6 & 41.7 & 13.9 & 18.8 & 9.8 & 12.5 & 51.3 & 61.2 & 42.0 & 484.1 & 1152.2 & 0.21 & 2.00 & 1.34 & 0.22 \\
\hline $\begin{array}{l}\text { Biomix + } \\
\text { Vermicompost } \\
\text { @ } 2.5 \mathrm{t} \mathrm{ha}^{-1}\end{array}$ & 115.2 & 40.3 & 13.1 & 19.0 & 11.4 & 14.0 & 55.6 & 64.8 & 50.6 & 519.8 & 1258.0 & 0.25 & 2.09 & 1.59 & 0.24 \\
\hline CD@ 5\% & 10.3 & 2.68 & NS & 1.29 & NS & 0.68 & 2.7 & 3.01 & 2.63 & 22.31 & 34.21 & 0.01 & 0.11 & NS & NS \\
\hline \multicolumn{16}{|l|}{ Nitrogen level } \\
\hline 70\% RDN & 151.0 & 50.7 & 15.7 & 15.3 & 9.1 & 11.5 & 46.3 & 54.9 & 35.8 & 382.3 & 924.4 & 0.17 & 1.55 & 1.15 & 0.19 \\
\hline $80 \%$ RDN & 134.7 & 43.1 & 13.8 & 18.1 & 10.2 & 12.5 & 49.4 & 58.6 & 40.9 & 459.9 & 1108.1 & 0.20 & 1.89 & 1.35 & 0.21 \\
\hline $90 \%$ RDN & 124.4 & 39.6 & 13.1 & 19.7 & 10.4 & 13.5 & 52.4 & 61.5 & 45.6 & 516.6 & 1228.4 & 0.22 & 2.12 & 1.43 & 0.23 \\
\hline $100 \%$ RDN & 120.2 & 38.7 & 12.7 & 20.1 & 10.9 & 13.6 & 53.9 & 63.5 & 47.2 & 529.8 & 1268.2 & 0.23 & 2.17 & 1.51 & 0.24 \\
\hline CD@ 5\% & 8.3 & 3.09 & 0.69 & 1.38 & NS & 0.80 & 2.06 & 2.18 & 2.49 & 29.65 & 40.13 & 0.01 & 0.14 & 0.21 & 0.02 \\
\hline
\end{tabular}




\section{Table.2}

\begin{tabular}{|c|c|c|c|c|c|c|c|c|c|c|c|c|}
\hline \multirow[t]{2}{*}{ Treatment } & \multicolumn{3}{|c|}{$\begin{array}{l}\text { Nutrient efficiency } \\
\text { ratio }(\mathrm{kg} / \mathrm{kg})\end{array}$} & \multicolumn{3}{|c|}{$\begin{array}{l}\text { Nutrient harvest } \\
\text { Index }(\%)\end{array}$} & \multicolumn{3}{|c|}{$\begin{array}{l}\text { Total nutrient } \\
\text { uptake (kg/ha) }\end{array}$} & \multirow{2}{*}{$\begin{array}{l}\text { Grain } \\
\text { Yield } \\
\text { (Mg/ ha) }\end{array}$} & \multirow{2}{*}{$\begin{array}{l}\text { Straw } \\
\text { Yield } \\
\text { (Mg/ } \\
\text { ha) }\end{array}$} & \multirow{2}{*}{$\begin{array}{l}\text { Biologic } \\
\text { al Yield } \\
\text { (Mg/ha) }\end{array}$} \\
\hline & $\mathrm{N}$ & $\mathrm{P}$ & $\mathrm{K}$ & $\mathrm{N}$ & $\mathrm{P}$ & $\mathrm{K}$ & $\mathrm{N}$ & $\mathrm{P}$ & $\mathrm{K}$ & & & \\
\hline \multicolumn{13}{|l|}{ Manures } \\
\hline Control & 110.8 & 474.0 & 92.1 & 50.8 & 27.5 & 12.9 & 77.3 & 17.7 & 91.6 & 2.3 & 5.6 & 7.9 \\
\hline Biomix & 103.9 & 437.6 & 89.6 & 50.1 & 26.1 & 12.9 & 86.9 & 20.4 & 100.5 & 2.6 & 6.3 & 8.9 \\
\hline $\begin{array}{l}\text { Vermicompost } \\
\text { @ } 2.5 \mathrm{t} \mathrm{ha}^{-1}\end{array}$ & 102.6 & 443.4 & 88.0 & 49.1 & 26.1 & 12.9 & 94.2 & 21.5 & 109.1 & 2.7 & 6.7 & 9.4 \\
\hline $\begin{array}{l}\text { Biomix }+ \\
\text { Vermicompost } \\
\text { @ } 2.5 \text { t ha }^{-1}\end{array}$ & 91.6 & 429.9 & 82.9 & 48.5 & 26.3 & 13.1 & 112.7 & 24.0 & 124.4 & 3.0 & 7.1 & 10.1 \\
\hline CD@5\% & 6.89 & 37.6 & NS & 2.3 & NS & NS & 8.0 & 1.80 & 12.3 & 0.1 & 0.4 & 0.5 \\
\hline \multicolumn{13}{|l|}{ Nitrogen level } \\
\hline $70 \%$ RDN & 118.6 & 478.7 & 91.8 & 51.6 & 26.0 & 12.8 & 71.3 & 17.5 & 90.8 & 2.4 & 5.9 & 8.3 \\
\hline $80 \%$ RDN & 105.8 & 447.7 & 90.1 & 50.1 & 26.2 & 12.9 & 87.5 & 20.4 & 102.9 & 2.6 & 6.5 & 9.1 \\
\hline $90 \%$ RDN & 95.2 & 429.9 & 86.3 & 49.1 & 26.6 & 13.0 & 101.6 & 22.6 & 114.1 & 2.8 & 6.8 & 9.6 \\
\hline $100 \%$ RDN & 89.2 & 428.6 & 84.2 & 47.7 & 27.1 & 13.2 & 110.7 & 23.1 & 117.8 & 2.9 & 6.9 & 9.8 \\
\hline CD@5\% & 5.7 & 38.6 & NS & 2.47 & NS & NS & 4.9 & 1.9 & 12.6 & 0.1 & 0.2 & 0.3 \\
\hline
\end{tabular}


As far as nutrient harvest index is concerned only the nitrogen harvest index was found significantly varying under different treatment and was found highest with $70 \%$ RDN (51.6 $\%$ ) which was at par with $80 \%$ RDN but significantly higher over $90 \% \mathrm{RDN}$ and $100 \%$ RDN. All these can be attributed to the point that with the application of biomix, vermicompost and higher dose of nitrogen there was more total nutrient uptake as compared to increase in the biological yield and nutrient uptake by grain. The total uptake of nutrients increased significantly with the increasing level of nitrogen in association with biomix and vermicompost. The higher nitrogen uptake under higher levels of nitrogen was due to increased concentration of nitrogen in grain and stover and more dry matter production (grain and stover) of pearl millet. Similar findings have also been reported by Satyajeet et al. (2007). The increased uptake of phosphorous under biomix + vermicompost @ $2.5 \mathrm{t} \mathrm{ha}^{-1}$ could be attributed to the increased content of phosphorous and higher stover yield because of the fact that biomix + vermicompost @ 2.5 $\mathrm{t} \mathrm{ha}^{-1}$ might have enhanced the availability of phosphorous to plants and increased root growth and ability of plant roots to absorb more phosphorous. The total uptake of phosphorous increased significantly with the increasing levels of nitrogen due to increase in yield and more dry matter production and the same was with the potassium. In the manurial treatment, grain yield was found maximum with the treatment biomix + vermicompost@2.5 t ha $\mathrm{ha}^{-1}\left(3.0 \mathrm{Mg} \mathrm{ha}^{-1}\right)$ followed by vermicompost @ $2.5 \mathrm{t} \mathrm{ha}^{-1}$ (2.7 $\mathrm{Mg} \mathrm{ha}{ }^{-1}$ ) and differ significantly. Also, with the increase in the nitrogen level grain yield was maximum with 100 per cent RDN (2.9 $\mathrm{Mg} \mathrm{ha}^{-1}$ ) but did not differ significantly with 90 per cent RDN (2.8 $\mathrm{Mg} \mathrm{ha}^{-1}$ ). This increase in grain yield may be ascribed to better root growth and development, resulting in more nutrient uptake and higher dry matter accumulation per plant and its subsequent translocation to the developing panicle. Thus, balanced nutrition due to combined use of biomix, vermicompost and chemical fertilizers throughout the crop period probably resulted in better growth, enhanced yield attributes and finally yield. Under the manurial treatment highest stover yield was recorded with biomix + vermicompost @ $2.5 \mathrm{t}$ $\mathrm{ha}^{-1}\left(7.1 \mathrm{Mg} \mathrm{ha}^{-1}\right)$ and lowest in control (5.6 $\left.\mathrm{Mg} \mathrm{ha}{ }^{-1}\right)$ whereas under different nitrogen levels it was maximum with 100 per cent RDN (6.9 $\mathrm{Mg} \mathrm{ha}^{-1}$ ) and lowest with 70 per cent RDN (5.9 Mg ha ${ }^{-1}$ ). This increase in the stover yield may be attributed to the increased plant height, leaf area and dry matter production. Similar results have also been reported by Rathore et al. (2004).

\section{References}

Bagla, G., Singh, I., Yadav, S.K. and Kumar, P. 2008. Effect of organic and inorganic sources of nutrient supply on growth and yield parameters of pearl millet. Natnl. J. Pl. Improv., 10(1): 37-39.

Brady, N.C. and Weil, R.R. 2002.The nature and properties of soils, 13th edition, Prentice Hall, Upper Saddle River, New Jersey.

Fisher, R.A. 1950. Statistical methods for Agric. Res. Workers. IInd Ed. Oliver and Boyand. London.

Hameeda, B., Rupela, O.P., Reddy, G. and Satyavani, K. 2006. Application of plant growth promoting bacteria associated with composts and macrofauna for growth promotion of pearl millet (Pennisetum glaucum L.). Biol. Ferti. Soils, 43: 221-227.

Panse, V. G. and Sukhatme, P. U. 1961. Statistical methods for agricultural workers, ICAR, New Delhi.

Rathore V. S., Singh P. and Gautam R. C. 2006. Productivity and water- use 
efficiency of rainfed pearl millet (Pennisetum glaucum) as influenced by planting patterns and integrated nutrient management. Indian $\mathrm{J}$. of Agron., 51(1): 46-48.

Rathore V. S., Singh P and Gautam R. C. 2004. Influence of planting patterns and integrated nutrient management on yield, nutrient uptake and quality of rainfed pearl millet. Ann. of Agric. Res., 25 (3): 373-376.

Renu, Kumar A and Kumar P. 2017. The performance of new pearlmillet hybrids with green gram under sole cropping and intercropping systems in semi-arid environment. Forage Res., 43 (1): 26-30.

Rinku, Shekhawat, P. S., Kumawat, N., Rathore, P. S., Yadav, P. K. and Om, Hari. 2014. Effect of nitrogen levels and biofertilizers on growth and yield of pearl millet (Pennisetum glaucum L.) under north western Rajasthan. Ann. Agric. Res., 35 (3): 311-314.

Sahai, V.N. 2011. Fundamentals of soil. $4^{\text {th }}$ rev. edition, Kalyani publishers, New Delhi-110002.

Satyajeet, Nanwal, R. K., Yadav, V. K.,
Pawan, K. 2007. Effect of integrated nutrient management on productivity and quality of pearl millet. Ann. of Bio., 23 (1): 37-40.

Singh, R., Gupta, A. K., Ram, T., Choudhary, G. L., and Sheoran, A.C. 2013a. Effect of integrated nitrogen management on transplanted pearlmillet (Pennisetum glaucum) under rainfed condition. Indian J. of Agron., 58 (1): 81-85.

Singh, R., Ram, T., Choudhary, G. L. and Gupta, A. K. 2013b. Effect of integrated nitrogen management on nutrient uptake, quality, economics and soil fertility of pearlmillet under rainfed conditions. Elix. Agric., 54: $12373-12375$.

Sinha, B. L., Chauhan, S. K. and Pradhan, M. K. (2011). Effect of tillage and nitrogen on growth and yield of pearl millet under rainfed conditions. Indian J. Soil Cons., 3: 220-225.

Sinha, B.L. 2015. Effect of tillage and nutrient management on yield of pearl millet and soil health in semi arid tropics. Internat. J. of IT, Engg. and App. Sci. Res., Vol. 4, No. 2.

\section{How to cite this article:}

Manjeet and Parveen Kumar. 2018. Growth Pattern, Nutrient use Ratio and Nutrient Harvest Index as Influenced by Nutrient Management in Pearlmillet. Int.J.Curr.Microbiol.App.Sci. 7(08): 2718-2725. doi: https://doi.org/10.20546/ijcmas.2018.708.284 